\title{
Kenduri: Traditional Culture in The Modern Society
}

\author{
Fisca Fitri Cahyani ${ }^{1}$, Ravik Karsidi ${ }^{2}$, Drajat Tri Kartono ${ }^{3}$ \\ \{fiscafitri@student.uns.ac.id ${ }^{1}$, ravik@staff.uns.ac.id ${ }^{2}$, drajattri@staff.uns.ac.id ${ }^{3}$ \} \\ 1,2 Universitas Sebelas Maret, Surakarta, Indonesia
}

\begin{abstract}
Kenduri is traditional culture of Java which purposes of expressing gratitude or sending a prayer to the deceased. This culture has a strong connected with ritual which was created by Wali Songo. This research is very important to do, for as a traditional culture, moderenitiy is not the main factor of this culture dissapearence. This reasearch uses partisipatoris methode which the researcher is required to stay with the local resident. Therefore, the researcher will get a valid data. Afterwards, the researcher analyzes it is using social constraction theory by Peter L. Berger. This theory is a theory of contemporary sociology, the born was based on the combination of the previous of so many social theories. From this research, the researcher get 3 steps dialectical process in soceity. The first one is externalization, the society is human being. It shows that a culture is something which is intentionally madeby the society. Through the objectivity, the society will be uniquely realistcs sui generis. It means, in the society occur a habit which autimatically create an organization; and through internalization, human is society. Some of them, left this tradition because it doesn't has islamic base and form of bid'ah.
\end{abstract}

Keywords: Kenduri, social constraction, dialectical process

\section{INTRODUCTION}

Society is a group of individu with some criteria. That is common territory, interaction with others, and have a special culture. Society or social group consist of two or more individu who interact and identify with others. Members of a society must be come in contact with another members. If a individu within a society has no contact regularly with another member, those individu is cannot be considered part of the same society. Geographic distance and language barriers can be separate societies within a country. It has rules (value) for make a system. In the same side, it has a punishment (norm) for control its member.

Javanesse society can be said have a more religious life. Their behaviour is affected by spiritual basis. Traditional ceremony is one of indonesian society habitual form which is still exist until now. Traditional ceremony has a role to always remind human with the existence and the relation with community environment. Until now the existence of religious ceremony 
is still admitted and the society do it very well, although in different for and different way. One of religious system in Javanesse society is called Kenduri. Kenduri is traditional culture of Java which purposes of expressing gratitude or sending a prayer to the deceased. Some of them perform this culture toward Ramadhan only, some of them perform in wedding ceremony, moving house, constructing house, being promotted, or some of them performed when Aqiqah. Kenduri which is always perfomed by Javanesse as a phenomenon that cannot be released for historical reliance. In the begining, Kenduri comes from Animisme Dinamisme reliance [1]. Trust of that forfathers' spirit cannot be released as such. Even though, modern javanesse still perform the Kenduri, because it has been attached in their mind that Kenduri is an obligatory ritual to be perfomed in their religion.

The more advanced a civilization, it should take a consequnce of social change for society, therefore, some of the system run into change. That change be in soceity understanding to value or sense of the exist tradition, because of the different understanding, therefore, the form of tradition will performed in different way. New experience, new technology, make people adjust their way of life and a new habit [2]. However, in Jombang Society, as the biggest region with Islamic Nadhatul Ulama (NU) basis, refer to by numbers of islamic boarding school until resting place of Gus Dur who were being a magnet for NU society to visit, make islamic culture in Jombang still exist until now. One of them is Kenduri. Kenduri is still attached in the society until now. Take a look at this phenomenon will be very interesting to research deeper about this modern culture, yet. Internalization system of a strong hereditary value can be one of durable factor this Islamic culture.

\section{METHOD}

This research is a qualitatif research which uses partisipatoris methode to collect data. This methode is choosen because by participate in every activity performed by the society, the researcher will get the more valid data. The collection of data is also done by doing in depth interview, started from religion leader (Pak Mudin), then the mosque manager, and also the society who perform Kenduri at their house. Then, the collected data is analyzed by using social construction theory of Peter L. Berger. This theory is used to see the interesting process which is in the outside of its individual (externalization), but as if that thing is in the inside of them (objectivitas). Furthermore, there is a withdrawall process into the inside (internalization), with the result that whom in the outside as if is in the inside each individual in their society [3].

\section{RESULT AND DISCUSSION}

Javanesse society is a religious society. Every performed activities completed by a series of custom ceremony [4]. Kenduri or offertory is one of main ceremony which is an important element on Javanesse religious system in general. Kenduri which is perfomed by Jombang society is consist of several kinds, that is when commemorating day of decease family member and it is purposing to send a prayer for the spirits. This kind of kenduri is performed after the corpse is buried. The implementation is based on first day count of the death day or it common called geblak. The kenduri is performed on the third day of the death day (kenduri telung dinoan), the seventh day of the death day (kenduri pitung dinoan), and then the fortieth day of the death day (kenduri petangpuluh dinoan / petangpuluhan), the hudredth day of the death day (kenduri satus dinoan / satusan), first year commemoration (kenduri setaunan), 
while the second year (kenduri pendaan), and the last is the thousandth day (kenduri sewunan).

Besides that, there is kenduri which is performed after the baby birth on a family. Same with death kenduri, birth Kenduri is performed in several step, that are sepasaran which is performed five day after the baby birth. The next is selapan which performed thirty five day after the baby birth. And the last is piton-piton which is performed when the baby is 7 months old. There are also Kenduri which is performed by one of family member who will marry. It is usually performed three or one day before the marriage is held.

The implementation of Kenduri (either death, birth, or marriage) is guided by religion leader who is called Pak Mudin. Besides that the implementation time is performed after maghrib time or after isya' at the house of the host. The invitation is usually not in a paper form, but the host invite by spoken directly to the neighbour. They are usually not invite in a long day before the event, but in a noon of the day before the event. Specifically for respected person in that society, besides being invited, the are also given hamper food (sego ater-ater).

\subsection{Social Externalization Process}

To be a human, an individual has to experience a personality development and cultural acquisition. Uncompleted human condition educationally when they was born, make it themselves unspecialized from their instinctive structure, or their world is not programed. Human world is a world constructed by the human's activity itself; they have to compose their own world on realtionship with the whole world [5]. The form of human's world is a culture, which purposes to form a substansial structures which are not owned by the human biologically before [6]. Because it is formed by the human, the structure is unstable and possibility could change. That is why, culture always recreated by human continously. It consists of human products, either material or nonmaterial. Human create various equipments, and by those equipments human changes physics environment and nature as its desire. Human creates language and build symbols which is pentrate all of its life aspects [7].

Meanwhile, unmaterial culture formation is always in compliance with human physics activity which change the nature. In fact, can be concluded that society is a part which cannot be separated from unmaterial culture. Society is an aspect from unmaterial culture which form connected relationship between human and its fellow. That is why, it create a world, that is social world. Society is the most special form of human social and usually it is called baha manusia homo sapiens (social creature) [8]. Therefore, human always live in collectivity, and will lost its collectivity if they isolated from other human. Human activity in creating world in essence is a colective activity. That collectivity carry out world building which is a social reality. The human create equipment, language, follow the values, and create foundations. The human also carries out social process as a keeper of social regulations.

In the interview with KH. Drs. M. Qoyim Yaqub, the Leader of Islamic Boarding School Al-Urwatul Wustqo, in January 13, 2019, he said "kenduri wi asale soko keinginane Wali jaman semono sing pengen ngajari masyarakat kabeh bab agama islam. Soale pas kuwi masyarakat wes kadung terbiasa karo adat Hindu-Budha. Islam iki agama sing rahmatanlil 'alamain dadi kudu dipelajari tapi budaya iki ora gampang lehe ngubah. Intine kenduri ki ora olo. Kenduri wi budaya sing mambu islam." (Kenduri is from the wish of Wali to teach Islam. Because, at that time, the society is used to belief Hindu-Budhism culture. Islam is a religion that is a rahmatanlil 'alamin, so it need to be learned. But, culture cannot be easyly change. The point is, kenduri is not a bad thing. Kenduri is just a society culture which is full of islamic value). Besides that, he also explained "kenduri ki lapo kok dilaksanakno ba'da magrib utowo ba'da isya'? soale sing diundang lek isuk sampek sore ki wayahe nyang sawah, 
na sing ngundang ki isuk sampek sore wajah e masak. Dadi masio ibadah kuwi penting banget tapi urusan dunya kui kanggo nyukupi urip, mongko ojo podo nyusahno tonggo." (Why does Kenduri is held after maghrib or isya'? Because the neighbour who is invited is still in field in the morning day until afternoon, and the host still cook at that time. So, even that worship is very important but that world matter is for fullfil the life. So, don't make it difficult to neighboor)

From the explanation above can be seen that society can build their own society and create values that could support a culture. The expoused values definitely based on necessity and habitual of local society. Height level of islamic belief in Jombang makes society keep regenerate the culture to be mix with Islam. Moreover, Kiai as a leader of islamic society said that Kenduri is a culture what is a good think and very useful for all member's relation. Besides that, they also form into habit which is rightly held.

\subsection{Social Objectivity Process}

A culture which is outside human subjectivity, become its own world. A world which is produced by human get objectivity reality character [9]. It means, all of human activities happened on externalization could experience habitual process (habitualization) which then experience institutionalization [10]. Intitutional comes from habitual from human activity. Every action which is not repeated, will be pattern in a habitual. Habituation, which is a pattern, can be done again in aonther time with the same way. Behind a habitual, it is very possible occur inovation. But, before there is habitual process it is always started by institutionalization. Institutionalization, happened if there is typification which is reciprocal from habitual actions. Action typification which has been a habit, which is forms institutions, is a shared property. Those typifications is available for all of social group member, and those institutions typify individual actor or its actions. That reciprocal typifications happened diacronically and not only once. Institutions also control human behaviour by creating behaviour systems [11]. These systems then control something which is adhering to institution. Segment human activity which is intitutionalized means placed under social control. In this case there is also punishment which is given to the member.

In a interview on January 14, 2019 Pak Mudin said "kenduri iku dipimpin karo Mudin. Lek kabeh ngadakno kenduri yo ra mungkin soale sak deso wi Mudin e mek siji dadi sing pingin ngadakno kenduri kudu daftar sek ndk masjid. Engko pengurus masjid laporan karo Pak Mudin" (Kenduri is led by Mudin. If every society is willing to held kenduri it is not possible because in one village there is ony one Mudin. Therefore, for those who is willing to held Kenduri has to register to the mosque. The committee of mosque will report to the Mudin). In implementation of Kenduri itself there no much changes. From the meals and procedure. The changes is only in food container or ambeng. Like Pak Mudin explained "Lek perubahan ya kaya-kaya ra ono. Mulai teko lauk, jajan, sampek pelaksanaan kabeh podo. Cuma sing beda $i k u$ adah ambeng e. Lek jaman biyen, mergo sek tradisional dadi adah e gawe godong gedhang. Lek sak iki mergo wes modern berubah dadi besek sing arang-arang kuwi, terus sak iki adah berkat sing teko plastik kae kyk mangkok, ora arang-arang." (The changes of Kenduri is almost not happened. Started from the meals, snack, until the procedures are the same. The different way is located in the food container which is called ambeng. In earlier times, because it was still traditional so they use banana leaf. At this time, because now is modern era, so people use holey plastic food container which is called is called besek. More modern, it changes again into covered continer like a bowl.

Because this culture has a structure, society made a punisment to control their member do the rules. The punishment is like a bad label from another member and that consistency will 
emergence the embarrassment. In the same time, Pak Mudin said "lek enek sing ora tau kenduri kuwi biasane wong sing wes bedo aliran. Wes rumongso paling bener. Wes koyo mati bakal budal dewe. Terus merakno rumongso sing paling bener dewe." (If member who do not want to do Kenduri usually they have difference thingking. They feel that they are the only one human who has the best comprehension on their religion).

From the explanation above, can be explained that the habit which is done has been experiencing internalization which manage that society habit. If they don't do as the same as the definition, they will get punishment, that is emergence the embarrassment. That feeling is from bad label. Meanwhile, the habit which is done continously has been changed. Eventhough, the change is not a big change.

\subsection{Social Internalization Process}

Internalization is a an individual comprehension or interprretation directly for objective event as the act of expressing a meaning. In the internalization, individual identify itself internalization atau social organization where the individual is as a member [12]. Internalization is a re-absorbed of reality by human and re-transform from objective world structures into subjective awareness structures [13]. That subjectivity is available objectively for people who is internalized and meaningfull, it doesn't matter is there are compatibility between the to subjectivity meaning. In this step, individual become a member of society [14]. The process to reach that level is held by socialization. There is two kind of socialization, that are: first, primary socialization, is first socialization and surely acceptable by the individual in a childhood. Second, secondary socialization, is every develompent process inti society.

According to the interview, Pak Mudin said "wong sing ora tau menglakoni kenduri neng kene iki biasane lek ora wong Muhammadiyah yo wong LDII. Soale menurut wong-wong iku kenduri kuwi ra ono hubungane karo islam. Dadi sing ngelakoni kenduri kaya wong NU ngene iki di arani bid'ah." (Fort those who is not held Kenduri is Muhammadiyah member and LDII member. According to them, kenduri is bid'ah). In the other side, the member who is judged as Muhammadiyah member, in interview on January 16, 2019, said "la pie mbak? Teko pengalamanku belajar agama kan memang Kenduri kuwi ra enek ndk ajaran agama islam. Sahabat Nabi ra enek sing ngelakoni ngono kuwi. Nyapo kok kudu Kenduri? Kan sunnah sing liyane yo akeh kok." (So what? I never know Islam talks about Kenduri. The companions of prophet Muhammad SAW never do that. Why do we have to do Kenduri? The fact is we have many much sunnah which we can do.)

From that statement can be explained on internalization steps, the people itself who is determine which habit finally they use. The mutation of this value is usually happened because there is a new knowledge which is according to that individual is make sense than a culture which has ben held [15]. It is causes after the people grow up, they have more experience and that will be a new knowledge for the people. From a thinking process, people will consider the best way for their life. Therefore, in the Berger theory talk that in the final socialization process, people will has authority to show their existence [16].

\section{CONCLUSION}

In modern era, culture has 3 proses. They are social externalization process that can build their own society and create values that could support a culture. The expoused values definitely based on necessity and habitual of local society. Besides that, they also form into habit which is rightly held; social objectivity process that that the habit which is done has been experiencing internalization which manage that society habit. If they don't do as the same as 
the definition, they will get punishment, that is cannot hel the Kenduri; social internalization process the people itself who is determine which habit finally they use. The mutation of this value is usually happened because there is a new knowledge which is according to that individual is make sense than a culture which has ben held.

\section{REFERENCE}

[1] Henderikus J Stam. "Social Constructionism and Its Critics," Theory \& Psychology, University of Calgary., Vol. 11 No 3, 2009

[2] Alan Sica, "Social Construction as Fantasy: Reconsidering Peter Berger and Thomas Luckmann's The Social Construction of Reality after 50 Years," Cultural Sociology., Vol. 10 No. 1, 2015.

[3] Ema Marhumah, "Konstruksi Sosial Gender Di Pesantren: Studi Kuasa Kiai Atas Wacana Perempuan” Jakarta: LkiS, 2011.

[4] Arfanda, "Konstruksi Sosial Masyarakat Terhadap Waria," Kritis, Jurnal Ilmu Sosial dan Politik Universitas Hasanuddin., Vol 1 No 1, 2015

[5] Charles R Ngangi, "Konstruksi Sosial dalam Realitas Sosial”, Agri-Sosioekonomi., vol. 7, no. 2, 2011.

[6] G. D. Abdul et.al. 2012). Da'wah Through Social Services Method: The Experience of the Department of Da'wah and Leadershi Studies, National niversity of Malaysia. Advances in Natural and A lied Sciences, (4), 545-548, 2012.

[7] Budhy Munawar-Rachman, "Fenomenologi Diri dan Konstruksi Sosial Mengenai Kebudayaan: Edmund Husserl dan Jejak-Jejaknya pada Maurice Merleau-Ponty dan Peter Berger," Ilmu Ushuluddin, Vol 1 No 6, July 2013.

[8] Griffin, Emory A. (2011). A First Look at Communication Theory, 8th ed. New York : McGraw-Hil, Inc.

[9] Brian A Roberts, "The Social Construction Of Music As A School Subject," Action, Criticism \& Theory for Music Education, Memorial University, Vol 3 No. 3, 2009.

[10] William A. Gamson, David Croteau, William Hoynes, And Theodore Sasson, "Media Images And The Social Construction Of Reality," Annual Review Of Sociology, Vol. 18. Pp. 373-393, 2012.

[11] Peter L Berger \& Thomas Luckmann, "Tafsir Sosial atas Kenyataan: Risalah tentang Sosiologi Pengetahuan", (diterjemahkan dari buku asli The Social Construction of Reality oleh Hasan Basari), Jakarta: LP3ES, 2014.

[12] Emory A Griffin,. A First Look at Communication Theory, 8th ed. New York : McGraw-Hil, Inc. 2011.

[13] Hall Stuart., Evans Jessica., Nixon Sean.. Representation, second edition. London, Thousand Oaks- California. New Delhi: SAGE Publications, Inc. 254-260, 2013.

[14] Wu, L., \& Liu, X. J. The China energy threat' thesis and Sino-U.S. relations: a critical review. ournal of Middle Eastern and Islamic Studies, (1), 31-45. 2007.

[15] G. D. Abdul et.al. . Enhancing Life Quality of Aboriginal People in Malaysia and its Relationship with Cultural Tourism. Advances in Natural and A lied Sciences, (4), 549551. 2012

[16] K. Saddhono, "Language of Coastal Communities in the Northern Coast of Central Java: Sociolinguistic Studies in Cultural Integration Maritime-Agrarian Perspective." Adv. Sci. Let. vol. 23 no. 10 pp 10054-10056, 2017 